\title{
40
}

\section{Dependencies of Long-Term Care Policy on East-West Migration: The Case of Germany}

\section{Karin Gottschall, Kristin Noack, and Heinz Rothgang}

\section{Introduction}

Only in recent decades has the need for long-term care (LTC) gained attention in welfare state policies. Against the backdrop of an ageing society, the dwindling availability of female family members to provide informal care and an inadequate public infrastructure, dependency on LTC provision has been acknowledged as a "new social risk" (Taylor-Gooby 2004) in most Western welfare states. While social democratic welfare regimes tend to resort to tax-financed public provision and liberal regimes to means-tested benefits and market-based provision, in 1995 the German Bismarckian welfare system introduced a two-tiered, mandatory longterm care insurance (LTCI) scheme as the fifth pillar of the social security system. In line with the subsidiarity principle, entitlements in cash are

K. Gottschall $\bullet$ K. Noack $\bullet$ H. Rothgang $(\bowtie)$

University of Bremen, Bremen, Germany

e-mail: karin.gottschall@uni-bremen.de; knoack@uni-bremen.de;

rothgang@uni-bremen.de 
given to support care at home by family members, which was regarded as the most favoured option, while at the same time alternative and supplementary benefits in kind were introduced with a view to expanding formal homecare and residential care capacities (Rothgang 2010). Despite diminishing family care capacities, today, more than half of all LTCI beneficiaries choose cash benefits and thus rely on informal care only (Rothgang et al. 2020a, 64). A major reason for this is the ability to use this money to pay informal workers, mainly women, from Eastern European countries to provide long-term care, often as live-ins and in mostly informal work arrangements. This type of care provision, the socalled "migrant-in-the-family" model, can be seen as an unexpected policy outcome, triggered by households' unanswered care needs and the supply of migrant care workers facilitated by European Union (EU) accession of Eastern European countries. Moreover, we also see an increasing dependency of the formal care sector on migrants. In fact, policy reactions to the ongoing demand for LTC from 2010 onwards have actively reflected the opportunity structure of foreign labour supply, by enhancing care work ${ }^{1}$ migration and care worker training in an even broader set of South-East European countries of origin. In parallel, a reform in training programmes and efforts to upgrade employment conditions and wages in formal outpatient and residential care have taken place, generating a mixed type of care provision (migrants in the family and migrants in formal care).

This contribution aims at reconstructing this policy shift from a Bismarckian "low road" to a "higher road" of service provision. In a nutshell: we argue that migration as a specific manifestation of interdependence has been playing a crucial role in both upholding and transforming long-term care policy in Germany.

First, we describe the institutional setting, in other words, the LTC insurance characterised by different aims and underlying logics regarding family-based elder care and formal care provision. We then turn to the unforeseen expansion of migrant care work, both in formal and informal

\footnotetext{
${ }^{1}$ In the following, care work is understood as a continuum ranging from informal care work performed in households, often by family members, to formal care work carried out in institutional settings such as outpatient or residential care, often requiring skilled work (Yeates 2009).
} 
LTC provision from the mid-nineties onwards and reconstruct this expansion as a result of labour market dynamics and migration regimes. Finally, we take a closer look at recent policy reforms actively addressing the limited supply of care workers and unattractive working conditions in formal care as well as the role of new actors enhancing the normalisation of informal work arrangements. Concluding remarks reflect on how the need for migrant care has transformed the German LTC system and what mechanisms have been at play.

\section{LTC Insurance as an Expansion and Economisation of the Bismarckian Welfare Regime}

According to $₫ 3$, Social Code Book XI, the primary goal of Germany’s LTCI is to strengthen homecare and to support family members, relatives and neighbours in order to enable care-dependent people to stay in their private households as long as possible (Vorrang der häuslichen Pflege). LTCI benefits directly linked to this goal are cash benefits for caredependent people (Pflegegeld), which they are completely free to spend as they see fit, and pension credits for informal caregivers. Support may also be provided by formal providers of homecare. The use of formal homecare, however, reduces the claim for cash, at a rate of roughly one to two; in other words, one Euro in cash lost for every two Euro spent on formal care. Additionally, benefits are granted for short-term care in residential homes, day care and substitutional care for informal carers if they need a break. If homecare is no longer possible, benefits for nursing-home care are provided; for the latter, however, co-payments are substantial, and costs for room and board as well as investment costs are to be paid out of pocket.

In effect, this set-up led to a utilisation of available benefits as shown in Table 40.1: The share of dependent people using cash benefits only is still over 50 percent, reflecting a remarkable stability of informal care. Within the formal sector a shift can be observed from nursing-home care (with a growth rate of 43 percent) to formal homecare (with a growth 
Table 40.1 Utilisation of LTCI benefits and formal care capacities

\begin{tabular}{|c|c|c|c|c|c|c|c|}
\hline \multirow[b]{2}{*}{ Year } & \multicolumn{4}{|c|}{ Beneficiaries in thousands: } & \multirow[b]{2}{*}{$\begin{array}{l}\text { Nursing } \\
\text { homes: } \\
\text { Beds }\end{array}$} & \multirow[b]{2}{*}{$\begin{array}{l}\text { Nursing } \\
\text { home: } \\
\text { Staff (fte) }\end{array}$} & \multirow{2}{*}{$\begin{array}{l}\text { Home- } \\
\text { care: } \\
\text { Staff } \\
\text { (fte) }\end{array}$} \\
\hline & $\begin{array}{l}\text { Cash } \\
\text { benefits }\end{array}$ & $\begin{array}{l}\text { Formal } \\
\text { homecare }\end{array}$ & $\begin{array}{l}\text { Nursing- } \\
\text { home } \\
\text { care }\end{array}$ & Total & & & \\
\hline 1999 & 1028 & 415 & 554 & 1997 & 622 & 345 & 184 \\
\hline 2001 & 1001 & 435 & 582 & 2018 & 649 & 370 & 190 \\
\hline 2003 & 987 & 450 & 612 & 2049 & 684 & 389 & 201 \\
\hline 2005 & 980 & 472 & 644 & 2096 & 726 & 405 & 214 \\
\hline 2007 & 1033 & 504 & 671 & 2208 & 766 & 421 & 236 \\
\hline 2009 & 1066 & 555 & 700 & 2321 & 808 & 453 & 269 \\
\hline 2012 & 1182 & 576 & 724 & 2482 & 831 & 480 & 291 \\
\hline 2013 & 1312 & 647 & 743 & 2702 & 848 & 491 & 320 \\
\hline 2015 & 1505 & 734 & 759 & 2998 & 866 & 525 & 356 \\
\hline 2017 & 1765 & 830 & 792 & 3387 & 877 & 553 & 390 \\
\hline 1999-2017 & 737 & 415 & 238 & 1390 & 255 & 208 & 206 \\
\hline $\begin{array}{l}\text { Growth } \\
\text { rate }\end{array}$ & $72 \%$ & $100 \%$ & $43 \%$ & $70 \%$ & $41 \%$ & $60 \%$ & $112 \%$ \\
\hline
\end{tabular}

Source: Rothgang and Müller (2019: 49, 76, 82)

rate of 100 percent). Interestingly, in both settings the total number of staff-measured in full-time equivalents (fte) - has increased more rapidly than the number of clients. While in homecare this might indicate a greater range of services used by each client, in nursing-home care this reflects an improvement in the staff-to-client ratio.

When LTCI was introduced, care capacities in the formal sector were low, leading to waiting lists in nursing homes and few chances of finding formal homecare over the weekend or at night (Rothgang 1997, 69). In order to improve this situation, the market was opened up for private for-profit care providers, and the legal primacy of public and (private) non-profit providers was abolished. Consequently, the subsequent growth of care capacities was almost completely produced by private care providers leading to a market share of 40 percent in nursing-home care and more than 50 percent in formal homecare by 2017 (cf. Fig. 40.1).

While on the surface the stabilisation of family care and the expansion of formal care seem to have been managed successfully, an in-depth analysis reveals that from the very beginning LTCI relied on conditions that 


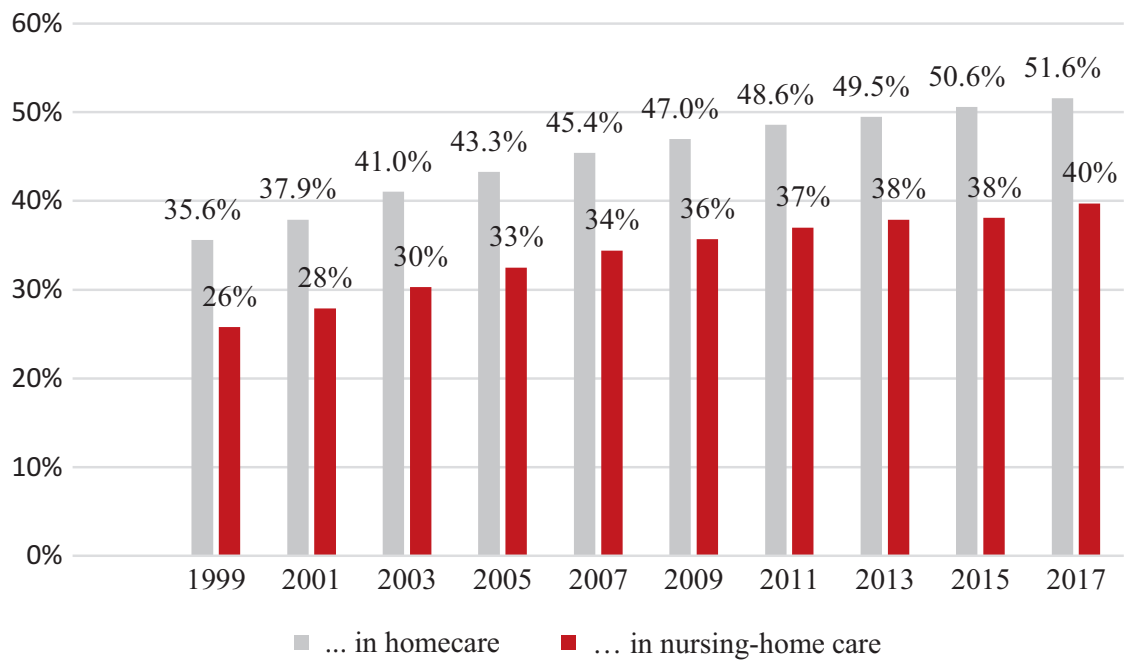

Fig. 40.1 Share of clients served by private providers in formal homecare and nursing-home care. (Source: Own calculation based on the Pflegestatistik published by the Statistisches Bundesamt every other year)

could not be reproduced by the system itself, namely sufficient domestic formal and informal caregivers. Instead, the system became increasingly dependent on an ever-increasing influx of migrant carers into both sectors.

\section{The Interaction between LTC Provision, Migration Regimes and Labour Market Dynamics}

Care migration is not a new phenomenon in Germany. Already in the 1960s and 1970s, health and care workers from Asia, predominantly South Korea, were recruited for formal care work (Braeseke and Bonin 2016). The most recent migrantisation process of care provision was triggered by the introduction of long-term care insurance in 1995, which boosted demand for all kinds of care services, and the fall of the Iron Curtain, driving many people to migrate West to find work and improve their livelihoods. Originally, many migrants found work in households 
supporting informal domestic and care work. Since then, however, demand for care services in Germany has mushroomed, driven by population ageing, changing family structures and high turnover rates in formal care. Migrants from EU countries, but also progressively from other parts of the world, work both in families and in institutional care, filling care gaps. Whereas until recently policy-makers largely turned a blind eye to the presence of the former, recruitment from abroad has now even become a political strategy for answering professional care needs in care institutions.

Since the 1990s, households have started hiring migrants privately to provide twenty-four-hour care to care-dependent people, ranging from domestic work to caring activities. Usually at least two migrants work for one household in rotation, alternating after several weeks or months. Most of these so-called live-in ${ }^{2}$ workers come from Central and Eastern European countries, predominantly Poland but more recently also further east. The liberalisation of the EU migration regime-through Eastern enlargement and visa relaxations, for example for Ukraineaccelerated this process from 2011, leading to the rapid development of commercial placement agencies that are meanwhile crucial in organising this type of care provision (Rossow and Leiber 2017). As these migrants generally work irregularly, there is limited administrative data on the phenomenon, but estimates indicate that it is expanding. Whereas a decade ago, approximately 200,000 migrants worked in households (Neuhaus et al. 2009), most recent estimates suggest there are around 500,000 (Benazha and Lutz 2019, 153) — a setting unquestionably promoted and upheld by LTCI cash benefits. In most cases, working conditions of liveins are at odds with legal regulations on minimum wages and working hours. Obviously, many families rely on migrant care workers because formal care alternatives are far more expensive. Hence, policy intervention to limit these arrangements is extremely delicate.

While the establishment and salience of a "migrant-in-the-family" model for providing LTC can be seen as an unexpected policy outcome,

\footnotetext{
${ }^{2}$ The academic literature employs this term to emphasise the precarity of the arrangement, namely that migrant workers live at their place of work and are at the care-dependent person's disposal twenty-four/seven.
} 
the increasing presence of a migrant workforce in formal care seems more driven by explicit policies. From 2013 to 2019, the absolute number of foreign workers ${ }^{3}$ in different occupations classed as formal care work $^{4}$ doubled. Whereas in 2013, only 5.3 percent of all care workers were foreign workers, by 2019 the share was at 10 percent. This difference becomes even more pronounced if one only looks at data on elder care professions, where the share of foreign workers increased from 6.8 percent in 2013 to 13.6 percent in $2019 .^{5}$ In that year, the top countries of origin were Poland, Bosnia-Herzegovina, Turkey and Romania. In part, the data reflect Germany's increased efforts to promote recruitment of skilled care workers from abroad since the early 2010s. The previously restrictive migration regime has been adapted to labour market needs, laying the path for high-skilled labour migration from non-EU countries. Whereas EU migrants benefit from harmonised recognition of credentials and free movement, non-EU citizens have to apply for individual residence and work permits in conjunction with a case-by-case review of their professional qualifications. The 2013 amendment to employment regulations makes it easier for non-EU citizens with non-academic vocational credentials in shortage professions such as care work to obtain residence permits, subject to approval by employment services (Braeseke and Bonin 2016). To facilitate the recognition of foreign qualifications, the legal basis was updated in 2012. In the same vein, recent measures led to the establishment in 2019 of a federal agency dedicated to skilled workers in health and care professions. Additionally, several bilateral agreements with non-EU countries have been concluded, notably with BosniaHerzegovina, Serbia and the Philippines, targeting both skilled care workers and people seeking an apprenticeship in care in Germany. Yet in elder care, migrants are still more numerous in lower-skilled occupations, indicating a segmented labour market (Khalil et al. 2020).

\footnotetext{
${ }^{3}$ The official data from the Federal Employment Agency refers to people with foreign citizenship. Even though it does not fully cover all migrants (especially naturalised), it is the most comprehensive data available on migrant workers in formal care.

${ }^{4}$ Own calculations based on a special analysis of data retrieved from the Federal Employment Agency in March 2020. Statistics include summarised data on insured employment in the occupational categories 813 (medical and healthcare professions, rescue services, midwifery) and 821 (geriatric nurses $=$ Altenpflege) .

${ }^{5}$ The average share of foreign workers in insured employment in 2019 was 12.5 percent.
} 


\section{Towards a "Higher Road" of Formal LTC Provision: Proactive Labour Policies and Normalisation of Migrant Care Work}

Historically, the female-dominated jobs in nursing, childcare and longterm care in Germany have been characterised by semi-professionalism, lacking established institutions of self-governance and central state regulation regarding training standards, access, remuneration and interest representation which are typical for male-dominated core professions such as medicine and law (Gottschall 2008). While nursing has gradually become more regulated, semi-professionalism in long-term care has persisted alongside an expansion of the sector and even become more pronounced after opening the market to private providers from the mid-1990s onwards. The latter weakened the historically strong role of religious and other non-profit service providers, who especially in the case of religious organisations provided long-term care services based on a mixture of paid and unpaid work and purposely refrained from applying the German legal framework for workers' interest representation. However, long-term care provision continued to be characterised by high rates of part-time work and low membership rates of workers in professional bodies and unions. Moreover, wages and working conditions remained on a low level as compared to nursing and contributed to high turnover rates and ongoing difficulties in filling open positions (Schröder 2018). Regional states and providers attempted to address the labour shortage by expanding short-term training programmes and positions, open to low-qualified younger and middle-age entrants and migrants. At the same time, the introduction of public health study programmes at universities aimed at professionalising management and provision in the field of health and long-term care. Taken together, these trends in training and recruitment indicate an increase in workforce stratification and segmentation in the field (Haasler and Gottschall 2015).

Irrespective of these trends, more recent labour market and healthcare reforms might indicate a more comprehensive, quality-oriented approach towards formal long-term care provision. They are targeted at improving the quality of care, as various actors in the field have been demanding for 
two decades already, and addressing pay, education and training as well as working conditions.

The introduction of the general minimum wage in 2016 and the more recent specific wage upgrading regulations for the long-term care sector are expected to improve wages in formal long-term care, which, however, assessed against the OECD_Organisation for Economic Co-operation and Development-low-wage threshold in 2019, are still very low (Ludwig and Evans 2020, 16). The wage agreement for public care providers reached in December 2020, amounting to a 10 percent increase and granting equal wages for qualified staff in hospitals and nursing homes, points to a clear upward trend (Greß and Stegmüller 2019)_-in line with the agreement reached by providers, health and long-term care funds and unions in the Konzertierte Aktion Pflege (Concerted Action for Nursing), jointly initiated and supervised by the Federal Ministry of Health, the Federal Ministry of Labour and Social Affairs, and the Ministry for Family Affairs, Senior Citizens, Women and Youth.

With respect to training, in 2017, after complicated political discussions between the different stakeholders, a comprehensive central state reform in training for nursing and long-term care, the Pflegeberufegesetz of 17 July 2017 (BGBl. I 2581), came into being. The new three-year training programme integrates and standardises the hitherto separate training programmes for both fields and, especially for long-term care, implies an upgrading and standardisation of the previous regionally heterogeneous training schemes, although it does not offset regional state governance and the co-existence of shorter training programmes. While the long-term aim of the reformed training programme is to attract a larger domestic workforce, currently there are also intense efforts to recruit and train workers abroad. Reflecting results from labour market workforce projections, which predict an ongoing severe labour shortage in long-term care without inflows of foreign workers (Bogai 2017), a bundle of measurements to attract foreign (geriatric) nurses has been taken (Bundesregierung 2020, working group four "Pflegekräfte aus dem Ausland"). Recent government initiatives are especially targeting South Eastern European non-EU member states whose labour markets still provide a workforce "reservoir" for migration; moreover, there are also 
initiatives targeting countries such as Mexico and the Philippines, recently visited by the Minister of Health and his Parliamentary State Secretary respectively. ${ }^{6}$

Finally, in 2017 the legislature commissioned the development of an instrument for calculating nursing staff requirements for nursing homes, not least reflecting the public debate on insufficient quality of long-term care in nursing homes. By summer 2020, the instrument was completed and publicly presented. In effect, it demands an increase in nursing personnel by more than one-third with an internal reorganisation of work processes to allow nurses with a minimum of three years' training to concentrate on complex tasks, while more nurses with one-to-two years' training relieve them from simpler tasks (Rothgang et al. 2020b). All relevant actors in the field agreed to implement this instrument. As a first step, an Act to Improve Health and Long-Term Care Provision (Gesundheitsversorgungs- und Pflegeverbesserungsgesetz) was recently passed by Parliament, providing among other things for an increase in the number of (refinanced) full-time equivalents in nursing homes of 20,000, in other words, about six to seven percent of the current staff, while further steps are currently being discussed in a roadmap process.

Furthermore, the Minister of Health has also made a proposal to reform the LTCI financing framework including the introduction of tax revenues to compensate higher costs for better pay and higher staff ratios.

\section{Conclusion}

On the face of it, German LTCI has been very successful with respect to its own goal of familialistic service provision: family care, which was regarded as the preferred option of families and society as a whole, was stabilised, while the scope of complementary formal homecare services as well as substitutional formal nursing-home services has been expanded. However, as neither family care capacities and willingness nor domestic labour supplies increased with the necessary speed, the inflow of migrant

\footnotetext{
${ }^{6}$ https://www.bundesgesundheitsministerium.de/ministerium/meldungen/2019/pflegekraeftephilippinen.html; Bundestags-Drucksache 19/2455.
} 
workers into the formal and informal sector became a necessary condition for upholding the system.

While public policy ignored these developments for some time, measures have recently been taken. On the one hand, attempts were started to make the nursing profession more attractive for the domestic workforce while at the same time the Ministry of Health actively sought to recruit qualified nurses from abroad under identical working conditions to those of the domestic labour force. In this respect, migrantisation does not necessarily lead to a de-professionalisation, but might be accompanied by a change from the low to the high road.

On the other hand, the Ministry of Health's most recent suggestion, to allow the use of up to 40 percent of the benefits for professional homecare to finance live-ins, must be considered as an "official" acknowledgement of this type of care arrangement and an attempt to "regulate" the current highly irregular working conditions of informal migrant caregivers rather than limit them. This strategy reflects the ongoing ambivalence of public policy in this field. The more or less explicit support for the "migrant-in-the-family" model also reflects the continued dependence of the German LTC system on such solutions, since formal homecare, formal nursing-home care, and live-in care based on forty-hour-a-week contracts (rather than the implicit expectation of twenty-four/seven services) are quite expensive and beyond the financial means of the majority of households. Therefore, unless the LTCI benefit caps are lifted, it is unlikely that effective measures to restrain the irregular working conditions of informal caregivers in private households will be taken.

From a bird's eye perspective, the above story can also be read as a kind of "drift" in the sense of Streeck and Thelen's reform typology (2005). A given institutional framework has been upheld, but the underlying processes have changed. Cash benefits have not stabilised the ability of families to care for their dependent members. Rather, they are increasingly used to establish a "migrant-in-the-family" model in Germany. The marketisation of care services indeed led to an expansion of services by private for-profit providers. This process, however, also depended on migrant carers, which was not initially envisaged. Only when even the migrant inflow in formal care proved to be insufficient to satisfy ever-growing demands-heightened further by policy adjustments to better meet the 
specific needs of people with dementia, which in turn led to a substantial increase in entitlements-were policy measures initiated to make the long-term care nursing profession more attractive.

In a nutshell, events and processes driving migrantisation could be summarised as follows: (1) the introduction of LTCI aimed at perpetuating the already existing dual structure of family care and formal care. (2) Due to demographic change an ever-increasing number of caregivers has been needed in both arrangements. After a while, however, decreasing family care potential on the one hand and insufficiently attractive working conditions in the formal care sector on the other hand rendered a respective increase in the number of domestic caregivers impossible and created mounting problem pressure. (3) As migration within the EU and the huge wealth gap between Germany and its eastern neighbours opened up opportunities for migration, an inflow of migrant carers into both formal and informal care followed, feeding the migrant-in-the-family model and migrant-in-formal-care alike. (4) While the government now actively recruits foreign (geriatric) nurses into the formal care sector and at the same time tries to improve the attractiveness of the profession, attempts have started to regulate the migrant-in-the-family model by allowing the use of established benefits for financing this type of provision once certain conditions are met.

Interestingly, policies to improve working conditions and pay in formal care may benefit domestic and migrant carers alike, the latter being still in heavy demand, while attempts to "regulate" live-in arrangements might diminish the share of highly irregular working arrangements for migrant live-ins. At the same time, reflecting the familialistic Bismarckian legacy, long-term care provision and its (female) workforce has become more stratified.

Acknowledgements This chapter is a product of the research conducted in the Collaborative Research Center "Global Dynamics of Social Policy" at the University of Bremen. The centre is funded by the Deutsche Forschungsgemeinschaft (DFG, German Research Foundation)_-project number 374666841-SFB 1342. 


\section{References}

Benazha, Aranka Vanessa, and Helma Lutz. 2019. Intersektionale Perspektiven auf die Pflege: Geschlechterverhältnisse und Migrationsprozesse. In Interessenvertretung und Care: Voraussetzungen, Akteure und Handlungsebenen, ed. Clarissa Rudolph and Katja Schmidt, 146-160. Münster: Westfälisches Dampfboot.

Bogai, Dieter. 2017. Der Arbeitsmarkt für Pflegekräfte im Wohlfahrtsstaat. Berlin and Boston: De Gruyter Oldenbourg.

Braeseke, Grit, and Holger Bonin. 2016. Internationale Fachkräfte in der Pflege. In Pflege-Report 2016, ed. Klaus Jacobs, Adelheid Kuhlmey, Stefan Greß, Jürgen Klauber, and Antje Schwinger, 254-261. Stuttgart: Schattauer.

Bundesregierung. 2020. Konzertierte Aktion Pflege. Erster Bericht zum Stand der Umsetzung der Vereinbarungen der Arbeitsgruppen 1-5. https://www. bundesgesundheitsministerium.de/fileadmin/Dateien/5_Publikationen/ Pflege/Berichte/2020-11-13_1._Bericht_zum_Stand_der_Umsetzung der_KAP.PDF.

Gottschall, Karin. 2008. Soziale Dienstleistungen zwischen Informalisierung und Professionalisierung oder: der Schwierige Abschied vom Deutschen Erbe Sozialpolitischer Regulierung. Arbeit. Zeitschrift für Arbeitsforschung, Arbeitsgestaltung und Arbeitspolitik 17 (4): 254-267.

Greß, Stefan, and Klaus Stegmüller. 2019. Vergütung von Pflegekräften in der Langzeitpflege. In Pflege-Report 2019, ed. Klaus Jacobs, Adelheid Kuhlmey, Stefan Greß, Jürgen Klauber and Antje Schwinger, 159-66. Berlin: Springer. Haasler, Simone R., and Karin Gottschall. 2015. Still a Perfect Model? The Gender Impact of Vocational Training in Germany. Journal of Vocational Education \& Training (JVET), Special Issue on "Gender in Vocational Education and Training: Pathways, Process and Practice" 67 (1): 78-92.

Khalil, Samir, Almuth Lietz, and Sabrina J. Mayer. 2020. Systemrelevant und Prekär Beschäftigt. Wie Migrant*innen unser Gemeinwesen Aufrechterhalten. DeZIM Research Notes DRN 3/20, May 25, 2020. Berlin: DeZIM-Institut.

Ludwig, Christine, and Michaela Evans. 2020. Löhne in der Altenpflege: Helferniveaus im Spiegel von Fachkräftesicherung und Lohnverteilung. IAT Forschung Aktuell 11/2020. Gelsenkirchen: Institut Arbeit und Technik.

Neuhaus, Andrea, Michael Isfort, and Frank Weidner. 2009. Situation und Bedarfe von Familien mit Mittel- und Osteuropäischen Haushaltshilfen. Köln: Deutsches Institut für angewandte Pflegeforschung e.V. 
Rossow, Verena, and Simone Leiber. 2017. Zwischen Vermarktlichung und Europäisierung: Die Wachsende Bedeutung Transnational Agierender Vermittlungsagenturen in der Häuslichen Pflege in Deutschland. Sozialer Fortschritt 66 (3-4): 285-302.

Rothgang, Heinz. 1997. Ziele und Wirkungen der Pflegeversicherung. Eine Ökonomische Analyse. Schriften des Zentrums für Sozialpolitik, Band 7. Frankfurt: Campus.

. 2010. Social Insurance for Long-Term Care: An Evaluation of the German Model. Social Policy and Administration 44 (4): 436-460.

Rothgang, Heinz, and Rolf Müller. 2019. BARMER Pflegereport 2019: Ambulantisierung der Pflege. Accessed November 30, 2020. https://www. socium.uni-bremen.de/uploads/News/2019/20191128_BARMER_ Pflegereport_2019.pdf.

Rothgang, Heinz, Benedikt Preuß, and Rolf Müller. 2020a. BARMER Pflegereport 2020. Belastungen der Pflegekräfte und ihre Folgen. Accessed November 30, 2020. https://www.socium.uni-bremen.de/uploads/ News/2020/20201201_BARMER_Pflegereport_2020.pdf.

Rothgang, Heinz, Stefan Görres, Ingrid Darmann-Fink, Karin Wolf-Ostermann, Guido Becke, Werner Brannath, Janet Cordes, Mathias Fünfstück, Franziska Heinze, Thomas Kalwitzki, Claudia Stolle, Stephan Kloep, Agata Krempa, Lukas Mazner, Cora Zenz, and Sarah Sticht. 2020b. Abschlussbericht im Projekt Entwicklung eines wissenschaftlich fundierten Verfahrens zur Einheitlichen Bemessung des Personalbedarfs in Pflegeeinrichtungen nach Qualitativen und Quantitativen Maßstäben gemäß \$113c SGB XI (PeBeM). Accessed November 30, 2020. https:/www.gs-qsa-pflege.de/wp-content/ uploads/2020/09/Abschlussbericht_PeBeM.pdf.

Schröder, Wolfgang. 2018. Interessenvertretung in der Altenpflege. Zwischen Staatszentrierung und Selbstorganisation. Wiesbaden: Springer VS.

Streeck, Wolfgang, and Kathleen Thelen. 2005. Introduction: Institutional Change in Advanced Political Economies. In Beyond Continuity: Institutional Change in Advanced Political Economies, ed. Wolfgang Streeck and Kathleen Thelen, 1-39. Oxford: Oxford University Press.

Taylor-Gooby, Peter. 2004. New Risks and Social Change. In New Risks, New Welfare. The Transformation of the European Welfare State, ed. Peter TaylorGooby, 1-28. Oxford and New York: Oxford University Press.

Yeates, Nicola. 2009. Globalizing Care Economies and Migrant Workers: Explorations in Global Care Chains. Houndmills and Basingstoke: Palgrave Macmillan. 
Open Access This chapter is licensed under the terms of the Creative Commons Attribution 4.0 International License (http://creativecommons.org/licenses/ by/4.0/), which permits use, sharing, adaptation, distribution and reproduction in any medium or format, as long as you give appropriate credit to the original author(s) and the source, provide a link to the Creative Commons licence and indicate if changes were made.

The images or other third party material in this chapter are included in the chapter's Creative Commons licence, unless indicated otherwise in a credit line to the material. If material is not included in the chapter's Creative Commons licence and your intended use is not permitted by statutory regulation or exceeds the permitted use, you will need to obtain permission directly from the copyright holder.

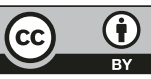

